\title{
Semen cryopreservation protocols of Mangalarga Marchador stallions
}

\author{
Marcela Leite Candeias ${ }^{1}$, Marco Antonio Alvarenga², Márcio Teoro do Carmo², Heder Nunes \\ Ferreira ${ }^{2}$, Mônica Russo Souto Maior ${ }^{3}$, Rodolpho de Almeida Torres Filho', André Luís Rios \\ Rodrigues' ${ }^{1}$, Felipe Zandonadi Brandão'
}

\footnotetext{
${ }^{1}$ Universidade Federal Fluminense - Faculdade de Veterinária - Rua Vital Brasil Filho, 64, CEP 24230-340, Niterói, RJ, Brazil.

2 Universidade Estadual Paulista "Julio de Mesquita Filho" - Faculdade de Medicina Veterinária e Zootecnia - Campus Botucatu - Botucatu, SP, Brazil.

${ }^{3}$ Médica Veterinária Autônoma.
}

ABSTRACT - The effect of the utilization of three semen protocols (Inra 82 ${ }^{\circledR}$, Merck Gema and Botu-crio ${ }^{\circledR}$ ) and two filling techniques $(0.25$ and $0.50 \mathrm{~mL}$ straws) in Mangalarga Marchador stallions were studied in this experiment. Sperm parameters were assessed during processing and post-freezing. No interactions between the protocols and type of filling were observed, so they were assessed separately. Sperm parameters were not altered when the extender was added to the centrifugation; however, there was reduction of motility and strength when freezing extenders were added. The Botu-crio ${ }^{\circledR}$ protocol preserved the parameters of total and progressive sperm motility, smoothed path velocity $(\mu \mathrm{m} / \mathrm{s})$, straight line velocity $(\mu \mathrm{m} / \mathrm{s})$, track velocity $(\mu \mathrm{m} / \mathrm{s})$ and the average and fast spermatozoa percentage better than the others. No difference between the extenders for the percentage of sperm integrity was observed. There was no difference in the responses studied on the filling techniques. The stallions presented better freezing with the use of the Botu-crio ${ }^{\circledR}$ protocol. The best post-freezing viability results were found for semen frozen using the Botu-crio ${ }^{\circledR}$ protocol and there were no differences concerning the sperm quality comparing 0.25 and $0.50 \mathrm{~mL}$ straws.

Key Words: ejaculated, equine, extender, straw

\section{Introduction}

The commercial interest in the artificial insemination technique using frozen semen is notorious. Due to that, research studies on equine semen cryopreservation have constantly been implemented and developed.

Equine semen cryopreservation represents an important tool to improve the genetic species by maximizing the use of good breeding. However, the fertility rates obtained from equines are still much lower than the ones obtained from bovine frozen semen (Fürst et al., 2005).

The use of frozen equine semen is still very limited, due to particular differences in both sperm freezing and individual ejaculation among stallions. Another factor that limits the utilization of frozen semen is the reduced tolerance of equine spermatozoa to the freezing and thawing processes (Fagundes et al., 2011).

It has already been proven that the breed factor interferes directly in the sperm cells resistance to the cryopreservation technique. The Mangalarga Marchador breed has shown unsatisfactory results related to semen cryopreservation when compared with breeds such as Jumper and Quarter Horse.
The rate fertility reduction verified after the freezing and thawing processes is mainly related to the damages caused to the functioning and the structures of the spermatozoa membranes (Parks \& Graham, 1992).

The composition of freezing semen extenders, as well as the protocols utilized, can affect the results of the cryopreservation process, which is one of the major preoccupations among researchers.

The amides have shown sufficient effectiveness concerning the equine semen cryopreservation, mainly among the stallions of low freezability such as those of the Mangalarga Marchador breed (Alvarenga et al., 2005).

The objective of this study was to evaluate, in Mangalarga Marchador breed stallions, the utilization of three cryopreservation protocols and two filling techniques in the sperm viability during and after a semen cryopreservation.

\section{Material and Methods}

Twelve (12) Mangalarga Marchador stallions aging four to twenty-two years of age ( $8.28 \pm 5.13$ years), were used. Before the breeding evaluation, exhausting of all the 
sperm extra-gonadotropin from the animals was done. This procedure followed an every-other-day daily collection. Animals passing the andrologic tests, according to patterns established by Colegio Brasileiro de Reproduçao Animal - CBRA (1998), were used. Following this procedure, each breeder was subjected to two semen collections (artificial vagina), on an every-other-day basis, totaling twenty-four (24) frozen ejaculations.

Immediately after the collection, microscopic (color, aspect, odor, and volume) and semen microscopic (total motility, strengths, and spermatic concentrations) analyses were done through optic microscopy enhanced to 200x. After the analyses, only the ejaculates that contained semen volume with concentration of $1.8 \times 10^{9}$ of viable spermatozoa and presented $60 \%$ total minimum motility were subjected to the freezing process.

Following this procedure, the semen was diluted by means of centrifugation in skimmed milk (Botu-semen ${ }^{\circledR}$ Biotech Botucatu, Botucatu, São Paulo, Brasil) at 1:1 ratio, and then this semen was evaluated as for its spermatic motility and strength. Later, it was centrifuged for 10 minutes in a macro-centrifuge (Centrifuga de Bancada Baby $^{\circledR}$ - Modelo 206BL-Fanem ${ }^{\circledR}$, São Paulo, SP, Brasil).

Following centrifugation, a re-suspension of the straws with the extenders of freezing, according to each experimental group (Table 1) was done, so as to obtain a $1 \mathrm{~mL}$ dilution rate from the freezing extender to 100 million of viable spermatic cells. After the dilution with the extenders of freezing, a new evaluation related to the motility and sperm strength was accomplished in optical microscopy enhanced to 200x. The following freezing extenders were used: Inra82 ${ }^{\circledR}$ (FR4 Nutricell Nutrientes Celulares $^{\circledR}$, Campinas, São Paulo, Brasil, adding 4\% of glycerol), Botu-crio ${ }^{\circledR}$ (Biotech Botucatu, Botucatu, São Paulo, Brazil) and Merck Gema (according to Martin et al., 1949 ) added to $4 \%$ of glycerol. The ejaculates were divided in six experimental groups (Table 1), formed according to cryopreservation protocol (Inra $82^{\circledR}$, Botu-crio ${ }^{\circledR}$ and Merck Gema) and the filling method ( 0.25 and $0.50 \mathrm{~mL}$ straws).

After a dilution with the freezing extenders, semen was filled in 0.25 and 0.50 French straws (IMV Technologies, France) which were appropriately sealed (Imap Seladoras, Ribeirão Preto, São Paulo, Brazil). This way, the spermatic concentration inside the $0.50 \mathrm{~mL}$ straw was of 50 million

Table 1 - Division of experimental groups used in this study

\begin{tabular}{lcc}
\hline Cryopreservation protocols/filling & $0.25 \mathrm{~mL}$ straws & $0.50 \mathrm{~mL}$ straws \\
\hline Inra $82^{\circledR}$ & GI & GII \\
Botu-crio ${ }^{\circledR}$ & GIII & GIV \\
Merck Gema & GV & GVI
\end{tabular}

viable spermatozoa and in the $0.25 \mathrm{~mL}$ one, 25 million viable spermatozoa.

Straws GI,GII and GIV were preserved in a semen freezing container (Botutainer ${ }^{\circledR}$ - São Paulo, Brasil), at $5{ }^{\circ} \mathrm{C}$ internal temperature; straws GI and GII were kept for 60 minutes and straws GIII and GIV were kept for 20 minutes. Subsequently, these straws were kept at a height of $4 \mathrm{~cm}$ liquid nitrogen for 20 minutes in an isotherm box.

The protocol utilized to straws GV and GVI consisted of placing all straws directly at a height of $4 \mathrm{~cm}$ of the liquid nitrogen level, packed in isotherm box for 20 minutes.

The thawing of samples was done in bain-marie at $46{ }^{\circ} \mathrm{C}$ for 20 seconds (Dell Aqua Junior et al., 2001b), which were subsequently preserved warmed at $37^{\circ} \mathrm{C}$ on a heating plate.

Computerized analyses were done using Hamilton Thorne $^{\circledR}$ equipment (IVOS-10 Sperm Analyzer, Hamilton Thorne Biosciences Inc, Bervely, MA, USA) for evaluation of the following spermatic variables: total motility (TM\%); progressive motility (PM\%); spermatic velocity along mean trajectory (VAP $\mu \mathrm{m} / \mathrm{s}$ ); spermatic velocity considering a straight line trajectory beginning at the first point analyzed and ending at the last point analyzed (VSL $\mu \mathrm{m} / \mathrm{s}$ ); spermatic velocity along the actual trajectory (VCL $\mu \mathrm{m} / \mathrm{s}$ ); and percentage of fast, average, slow and static spermatozoa.

For the evaluation of the plasmatic and acrosomal membrane integrity of the spermatozoon, fluorescent probes such as carboxyfluorescein diacetate (CFDA) and propidium iodide - PI (28,707-5-Sigma) were used, through technique by Harrison \& Vickers (1990), modified by Zúccari (1998), with the aid of epifluorescence microscope (Leica, DMIRB, Aotec Instrumentos Cientificos Ltda, São Paulo, SP, Brazil), with WB and WG filter at 400x magnification.

Software SAS (Statistical Analysis System, version 9.0) was used to accomplish statistic analyses (1996). For the pre and post phases, completley randomized design was utilized; in the pre-phase the effect of the centrifugation and freezing extender was evaluated, and in the post freezing phase, a $3 \times 2$ factorial arrangement (freezing extender $\times$ filling method) was utilized.

Concerning the variables related to the pre-freezing phase, the effect of the extender on the motility and strength were estimated by analyzing the range at $5 \%$ of probability. Comparing means, for motility, the Student-Newman-Keuls (SNK) test was used and for strength, since the response was non-parametric, the Kruskal-Wallis test was used.

Concerning the variables related to the post- freezing, normality test was conducted and for the variables that did not present normality, the modified logarithmic scale test 
was done (TM, PM, fast, average, slow, static percentage of intact spermatozoa).

After the logarithmic modification, variance analysis at $5 \%$ of probability was done and for the comparison of means, the SNK (Conover, 1980; Snedcor \& Cochran, 1980) was used.

The stallions studied were classified as for the semen freezing based on the total and progressive motility parameters (\%) with the studied extenders done in the postfreezing. Stallions that presented total average motility in the different extenders evaluated above $30 \%$ were classified as of acceptable freezing, and those which presented total motility below $30 \%$ were classified as not acceptable for freezing.

This experiment was approved by the Committee of Ethics on Animal Handling (Comitê de Ética em Uso de Animais) of Universidade Feferal Fluminense in October 2008 under no. 0044/08, so it was in accordance with the ethical principles of Animal Experiments of COBEA.

\section{Results and Discussion}

After adding the extender of centrifugation to the fresh semen, there was no alteration $(\mathrm{P}>0.05)$ in the seminal characteristics evaluated (Table 2). However, when adding the extenders of freezing to the semen post-centrifugation, there was effect on the characteristics evaluated, with a reduction in motility and strength, when compared with the fresh semen and the fresh diluted semen $(\mathrm{P}<0.05)$. However, when the Inra $82^{\circledR}$ extender was added, this reduction was greater in relation to the others (Botu-crio ${ }^{\circledR}$ and Merck Gema). There was no difference as for the addition of Botu-crio ${ }^{\circledR}$ and Merck Gema $(\mathrm{P}>0.05)$.

The results obtained from the pre-freezing evaluation are in accordance with Dell Aqua Junior et al. (2001a), whose parameters of total motility and spermatic strength of fresh semen diluted by centrifugation presented no differences. Besides, the average values of total motility verified in the fresh semen evaluation are consistent with the referred literature patterns (McKinnon \& Voss, 1993).
Nevertheless, with the addition of the freezing extender after the centrifugation, a reduction in motility and in the spermatic strength was observed, regardless of the extender used $(\mathrm{P}<0.05)$. This reduction was greater when adding Inra $^{\circledR} 82$, respectively, to fresh semen, semen diluted with centrifugation extender, Inra ${ }^{\circledR} 82$, Botu-crio ${ }^{\circledR}$ and Merck Gema. No literature studies in which comparisons were made were found. It is believed that these results are probably due to the fact that glycerol already presents toxic effect on the spermatic viability even before the cooling process. The presence of other components such as egg yolk at lower concentrations, as occurs in the Inra ${ }^{\circledR} 82$ extender in relation to the other extenders, could have given less protection to the sperm cell. According to Demick et al. (1976), glycerol is harmful to the equine sperm and causes reduction to the spermatic fecundation capacity even in the absence of freezing. Pace \& Sullivan (1975) stated that the addition of glycerol has shown to be harmful when used at high concentrations both in fresh and frozen semen. These pieces of information support this reduction in seminal parameters when freezing extenders are added to fresh semen.

There was no interaction between those responses, so, they were clustered so as to study effect of protocols $\left(\right.$ Inra $^{\circledR} 82 \times$ Merck Gema) and the kind of filling (pallets of $0.25 \mathrm{~mL} \times$ pallets of $0.50 \mathrm{~mL}$ ) individually on the different spermatic parameters evaluated.

In the evaluation of the effect of freezing protocols on the unfrozen semen (Table 3), it was observed that the protocol that utilized the extender Botu-crio ${ }^{\circledR}$ preserved the total and progressive spermatic motility parameters better compared with the one that utilized Meck Gama protocol and Inra ${ }^{\circledR} 82(\mathrm{P}<0.05)$. For the parameters VAP, VSL and $\operatorname{VCL}(\mu \mathrm{m} / \mathrm{s})$, Botu-crio ${ }^{\circledR}$ was superior $(\mathrm{P}<0.05)$ in relation to Merck Gema and Inra 82; however, in parameters VAP and VCL, Merck Gema and Inra 82 were even $(\mathrm{P}>0.05)$. The protocol that utilized Botu-crio ${ }^{\circledR}$ obtained better results in the percentage of fast and mean spermatozoa. Consequently, in relation to the slow and static spermatozoa, Merck Gema and Inra ${ }^{\circledR} 82$ presented greater results without differing between them $(\mathrm{P}>0.05)$.

Table 2 - Motility and strength in pre-freezing of fresh semen and diluted semen with centrifugation extender and freezing extenders of Mangalarga marchador stallions

\begin{tabular}{|c|c|c|}
\hline Items & Motility $(\%)^{1}$ & Strength $(0-5)$ \\
\hline Fresh semen & $83.54 \pm 8.14 \mathrm{~A}(24)$ & $3.63 \pm 0.49 \mathrm{~A}(24)$ \\
\hline Semen diluted with centrifugation extender & $86.04 \pm 6.75 \mathrm{~A}(24)$ & $3.98 \pm 0.28 \mathrm{~A}(24)$ \\
\hline Semen diluted with Inra $82^{\circledR}$ & $50.00 \pm 18.9 \mathrm{C}(20)$ & $2.25 \pm 0.64 \mathrm{C}(20)$ \\
\hline Semen diluted with Botu-crio ${ }^{\circledR}$ & $72.85 \pm 14.79 \mathrm{~B}(21)$ & $3.30 \pm 0.85 \mathrm{~B}(21)$ \\
\hline Semen diluted with Merck Gema & $68.57 \pm 14.41 \mathrm{~B}(21)$ & $3.19 \pm 0.68 \mathrm{~B}(21)$ \\
\hline
\end{tabular}

Means followed by different letters, in the same column, differ $(\mathrm{P}<0.05)$ according to the tests of Student-Newman-Keuls (motility) and Kruskal-Wallis (strength).

${ }^{1}$ Numbers in parenthesis refer to the number. 
No difference was observed $(\mathrm{P}>0.05)$ between extenders in the percentage of the integrity of the evaluated spermatozoa through the epifluorescence microscopy to Botu-crio ${ }^{\circledR}$, Merck Gema and Inra 82 (Table 3).

In the post-thawed evaluation, when the effects of freezing protocols were studied separately, values of spermatic motility (total and progressive) utilizing the Botu-crio ${ }^{\circledR}$ extender compared with the Merck and Inra $82^{\circledR}$ were obtained. The fact that the Protocol that utilizes Botu-crio ${ }^{\circledR}$ extender was superior to the others is probably due to the differences in the composition of their formulas, considering the presence and concentration of different cellular cryo-protectors, types of sugar utilized and the buffer system. The lower concentration of glycerol and the presence of methylformamide in the Botu-crio ${ }^{\circledR}$ probably promoted better post-thawing spermatic viability. According to Papa et al. (2002), this extender combines the association of methylformamide at $4 \%$ and the glycerol at $1 \%$ enriched with types of sugar and substrate of cellular cultivation as sources of macromolecules, plus the presence of egg yolk and skimmed milk.

Terraciano at al. (2008) pointed out that frozen samples in amide-based diluent resulted in a better progressive motility post-freezing compared with the FR5 diluent containing glycerol. These results corroborate the findings of the present study, in spite of the methodological differences used. The results of this study are in accordance with Melo at al. (2007), in which the use of glycerol at low concentrations (1\%) presented superior results in the post-thawing spermatic viability when combined with amides (4\% methylformamide) or even when used alone as cryo-protectants. However, glycerol toxicity was observed when the semen of the stallions that did not present good freezability was frozen, and this effect was minimized through a combination of glycerol and amides. Alvarenga et al. (2005) demonstrated that glycerol was the cryo-protectant that induced the most striking osmotic stress, presenting severe alterations in the motility, cellular viability and acrosome integrity parameters.

The parameters of total and progressive motility postthawing in glycerol and dimethylformamide observed by Medeiros etal.(2002) were, respectively: $27.00 \%$ and $8.00 \%$; and $52.00 \%$ and $12.00 \%$. Gomes et al. (2002) also found similar values: $42.75 \%$ and $13.50 \%$ to dimethylformamide and $14.56 \%$ to glycerol. When comparing the cryoprotectors glycerol and dimethylformamide, Gomes et al. (2002) observed a spermatic motility reduction using glycerol. In the present study, using means such as glycerol associated or not with the use of methylformamide, one can also observe that by using only glycerol, there is reduction in spermatic motility. The results obtained by Gomes et al. (2002) and Medeiros at al. (2002) match the results obtained in the present study, in which similar values $(41 \% ; 19.4 \%$ to Botu-crio ${ }^{\circledR}$ and $9.04 \% ; 3.0 \%$ to Inra $82^{\circledR}$ ) were found.

The hypothesis that amide-based cryo-protectants present higher cellular permeability causing less cellular damages seems quite plausible to the clarification of the results obtained with the cryoprotectants in the diluters studied, showing to be superior to glycerol. Terraciano et al. (2008) found more effectiveness in the equine semen cryopreservation utilizing Botu-crio ${ }^{\circledR}$ commercial diluents compared with FR5.

Among the various patterns of spermatic velocity obtained (VAP, VSL, and VCL), the results presented by the group that utilized the Botu-crio ${ }^{\circledR}$ extender were superior to the others. These results were different from the results reported by Ferreira (2008), in which the results in velocity did not differ between the cryo-protectants studied (Glycerol at 3\% and methylformamide at 3\%), as Medeiros et al. (2002), when evaluating methylformamide and glycerol at $5 \%$ concentration.

The results found for the percentage of fast and average spermatozoa were superior to Botu-crio ${ }^{\circledR}$; consequently, for the percentage of slow and static spermatozoa, INRA82R

Table 3 - Parameters evaluated in post-thawed semen of stallions of the Mangalarga Marchador breed in different cryopreservation protocols

\begin{tabular}{|c|c|c|c|}
\hline Parameters & Inra $82^{\circledR}$ & Botu-crio $^{\circledR}$ & Merck Gema \\
\hline Total motility (\%) & $9.04 \pm 7.58 \mathrm{c}(47)$ & $41.39 \pm 16.83 a(48)$ & $15.44 \pm 14.37 b(47)$ \\
\hline Progressive motility (\%) & $3.06 \pm 3.22 \mathrm{c}(47)$ & $19.37 \pm 12.10 \mathrm{a}(48)$ & $6.57 \pm 8.35 b(47)$ \\
\hline $\mathrm{VAP}(\mu \mathrm{m} / \mathrm{s})$ & $63.8 \pm 29.40 b(47)$ & $78.87 \pm 15.66 \mathrm{a}(48)$ & $67.17 \pm 10.08 b(47)$ \\
\hline $\mathrm{VSL}(\mu \mathrm{m} / \mathrm{s})$ & $50.31 \pm 22.27 \mathrm{~b}(47)$ & $66.64 \pm 12.76 \mathrm{a}(48)$ & $60.00 \pm 8.00 \mathrm{c}(47)$ \\
\hline $\operatorname{VCL}(\mu \mathrm{m} / \mathrm{s})$ & $121.12 \pm 60.65 b(47)$ & $150.68 \pm 24.34 \mathrm{a}(48)$ & $109.41 \pm 22.05 b(47)$ \\
\hline Fast spermatozoa (\%) & $4.61 \pm 4.53 \mathrm{c}(47)$ & $25.60 \pm 16.29 \mathrm{a}(48)$ & $7.82 \pm 10.89 b(47)$ \\
\hline Average spermatozoa (\%) & $4.27 \pm 3.81 \mathrm{c}(47)$ & $15.81 \pm 7.30 \mathrm{a}(48)$ & $7.48 \pm 5.44 b(47)$ \\
\hline Slow spermatozoa (\%) & $17.04 \pm 11.61 \mathrm{~b}(47)$ & $23.31 \pm 9.75 \mathrm{a}(48)$ & $17.04 \pm 17.36 \mathrm{~b}(47)$ \\
\hline Static spermatozoa (\%) & $65.51 \pm 25.41 \mathrm{a}(47)$ & $35.29 \pm 22.01 \mathrm{~b}(48)$ & $67.59 \pm 25.31 \mathrm{a}(47)$ \\
\hline
\end{tabular}

VAP - spermatic velocity along the mean trajectory $(\mathrm{VAP} \mu \mathrm{m} / \mathrm{s})$; VSL - spermatic velocity considering a straight trajectory with origin on the first point analyzed and the final on the last point analyzed; VCL - spermatic velocity along the actual trajectory.

Means followed by different letters, in the same row, differ $(\mathrm{P}<0.05)$ according to the Student-Newman-Keuls test (the number in parentheses refers to the number). 
and Merck Gema extenders showed no difference from each other. The values found are similar to those reported by Vidament et al. (2001), in which the percentage of fast spermatozoa was superior to the group that utilized methylformamide in relation to the group control and the group that utilized glycerol as cryo-protectant. Medeiros et al. (2002) also presented similar results in percentage of fast (RAPID) spermatozoa: $32.5 \%$ and $14 \%$ respectively to methylformamide at $5 \%$ and glycerol at $5 \%$. Medeiros (2007) obtained a higher percentage of fast spermatozoa when utilizing the methylformamide in relation to the others.

As for the plasmatic membrane integrity, no difference was observed between the protocols evaluated, as in Ferreira (2008) and Alvarenga et al. (2000). However, disagreeing with these results, Medeiros (2007) and Terraciano et al. (2008) found a superior percentage of intact cells when using amide in relation to glycerol.

In the freezability rate evaluation among stallions of the Mangalarga Marchador breed, according to the protocols evaluated, it was observed that all the stallions used in the present study presented low freezability when using INRA82 ${ }^{\circledR}$. Similar fact occurred when protocol with Merck Gema extender was used. However, when utilizing Botu-crio $^{\circledR}$, the majority of stallions presented post-thawed motility above $30 \%$ (Table 4 ).

Gomes at al. (2002) observed that the majority of Mangalarga Marchador breed stallions presented total motility below $30 \%$ after having semen frozen with glycerol.

In the study of Alvarenga et al. (2005), the percentage of stallions with post-thawing motility superior to $40 \%$ was $38 \%(21 / 55)$ for the semen frozen with glycerol and $80 \%(44 / 55)$ for animals with dimethylformamide. The same way, experiments in different species compared cryoprotectant solutions with amide and glycerol, attesting superiority of the solutions composed of amides (Hanada\& Nagase, 1980; Tselutin et al., 1999). This superiority can be related to their presumed mechanism of action and low molecular weight, when compared with glycerol, producing smaller osmotic aggression to the spermatic cell.

The explanation concerning the fact that the majority of the stallions used in this study presents a bad freezability, is

Table 4 - Stallion semen freezability of Mangalarga Marchador breed frozen in different cryopreservation protocols

\begin{tabular}{lcc}
\hline & Total motility above $30 \%$ & Total motility below $30 \%$ \\
\hline Inra82 $^{\circledR}$ & $0 / 12(0.00 \%)$ & $12 / 12(100.00 \%)$ \\
Botu-crio $^{\circledR}$ & $7 / 12(58.33 \%)$ & $5 / 12(41.67 \%)$ \\
Merck Gema & $1 / 12(8.33 \%)$ & $11 / 12(91.67 \%)$ \\
\hline
\end{tabular}

that the chosen stallions utilized in this experiment belong to the Mangalarga Marchador breed. According to Gomes et al. (2000), the use of amides in stallions with semen of good freezability does not provide increase in motility, but rather similar results when glycerol is utilized. However, in stallions that present low resistance to the cryopreservation, amides depict better results when compared with glycerol, as observed in the present study.

Holt (2000), in his review, affirmed that there are differences in the plasmatic membrane lipid compounds among species, breeds and even individuals belonging to the same species; this may be a reason why the very same means used can provide greater or smaller protection to the spermatozoa of a certain individual. Alvarenga et al. (2005) considered stallions, according to their semen-freezing pattern, as of "good freezing" and "bad freezing", and these two categories differed by the capacity of the spermatic cells to tolerate the harmful cryopreservation effects.

One of the factors involved in the sensitiveness of these individuals classified in the present study and the ones quoted by other authors as having low freezability, might be related to the physic-chemic glycerol characteristics, concerning viscosity and molecular weight. It is known that the stallion semen can respond differently to the cryopreservation depending on the type of extender utilized (Graham, 1996b). Furthermore, this variety of response to freezing presented by equine spermatozoa can be due to the lower proportion of cholesterol:phosphofolipids present in its plasmatic membrane, among other causes still unexplained (Parks \& Lynch, 1992). The variation in the plasmatic membrane fluidity can be one explanation to the variability in the semen freezibility observed among individual stallions. However, the utilization of these agents in stallions with low resistance to the cryopreservation process presents better results when compared with glycerol (Gomes et al., 2002).

Concerning the effect of the kind of filling studied, it was verified that the values of TM and PM of the frozenthawed semen, when 0.25 and $0.50 \mathrm{~mL}$ straws were used, did not show any difference $(\mathrm{P}>0.05)$. The same was true to the parameters of spermatic velocity such as VAP, VSL and VCL ( $P>0.05)$. The percentage of fast, average, slow and static spermatozoa and the percentage of intact spermatozoa also presented no difference $(\mathrm{P}>0.05)$ between the kinds of filling studied (Table 5).

According to Jasko (1994), because the straws present smaller diameter, they provide more homogenous freezing and post-freezing, resulting in better spermatic parameter values. The values obtained by Dell'Aqua Junior et al. (2001a) 
suggest the use of $0.25 \mathrm{~mL}$ straws as the most adequate to cryopreservation, because the $0.50 \mathrm{~mL}$ one presented results slightly inferior to that of $0.25 \mathrm{~mL}$. Nevertheless, some authors such as Papa et al. (1991) and Graham (1996a) observed a trend of better results using $0.50 \mathrm{~mL}$ straws.
Papa \& Dell'Aqua Junior (2001), when testing the packing of semen in $0.25 \mathrm{~mL}$ and $0.50 \mathrm{~mL}$ straws, observed that the motility and spermatic strength parameters presented no difference between each other, as in the results of this study.

Table 5 - Parameters assessed in the post-thawing of the semen of Mangalarga Marchador stallions frozen in two types of filling (0.25 and $0.50 \mathrm{~mL}$ straws)

\begin{tabular}{|c|c|c|}
\hline Parameters & $0.25 \mathrm{~mL}$ & $0.50 \mathrm{~mL}$ \\
\hline Total motility (\%) & $20.17 \pm 18.95(70)$ & $23.9 \pm 19.90(72)$ \\
\hline Progressive motility (\%) & $9.10 \pm 11.17(70)$ & $10.36 \pm 11.22(72)$ \\
\hline $\mathrm{VAP}(\mu \mathrm{m} / \mathrm{s})$ & $69.73 \pm 21.16(70)$ & $70.32 \pm 20.89(72)$ \\
\hline $\operatorname{VSL}(\mu \mathrm{m} / \mathrm{s})$ & $59.18 \pm 16.98(70)$ & $58.90 \pm 16.75(72)$ \\
\hline $\operatorname{VCL}(\mu \mathrm{m} / \mathrm{s})$ & $124.93 \pm 43.96(70)$ & $129.48 \pm 42.53(72)$ \\
\hline Fast spermatozoa (\%) & $11.77 \pm 14.51(70)$ & $13.75 \pm 15.18(72)$ \\
\hline Average spermatozoa (\%) & $8.35 \pm 7.14(70)$ & $10.09 \pm 7.77(72)$ \\
\hline Slow spermatozoa (\%) & $19.12 \pm 14.86(70)$ & $19.19 \pm 12.19(72)$ \\
\hline Static spermatozoa $(\%)$ & $57.84 \pm 29.11(70)$ & $54.18 \pm 27.61(72)$ \\
\hline Intact spermatozoa $(\%)$ & $33.74 \pm 12.78(70)$ & $33.63 \pm 13.94(72)$ \\
\hline
\end{tabular}

VAP - spermatic velocity along the mean trajectory (VAP $\mu \mathrm{m} / \mathrm{s}$ ); VSL - spermatic velocity considering a straight trajectory with origin at the first point analyzed and end at the last point; VCL - spermatic velocity along the actual trajectory.

\section{Conclusions}

The protocols that use extenders Inra $82^{\circledR}$ and Merck Gema with addition of $4 \%$ glycerol, unlike Botu-crio ${ }^{\circledR}$, were unfavorable for utilization in the cryopreservation of Mangalarga Marchador, regardless of the type of straw utilized.

\section{References}

ALVARENGA, M.A; PAPA, F.O.; LANDIM-ALVAENGA, F.C. et al. Amides as cryoprotectants for freezing stallion semen: A review, Animal Reproduction Science, v.89, p.105-13, 2005.

COLEGIO BRASILEIRO DE REPRODUÇÃO ANIMAL - CBRA. Manual para exame andrológico e avaliação de sêmen animal. 2.ed. Belo Horizonte: CBRA, 1998. 49p.

CONOVER, W.J. Practical nonparametric statistics. New York: Wiley, 1980. 493p.

DELL'AQUA JUNIOR, J.A.; PAPA, F.O.; ALVARENGA, M.A. et al. Effect of centrifugation and packing system on sperm parameters of equine frozen semen. Animal Reproduction Science, v.68, n.3-4, p.324-325, 2001a.

DELL'AQUA JUNIOR; J.A.; PAPA, F.O.; ALVARENGA, M.A. Effect of warming rate on sperm parameters and of insemination site and dose on the fertility of equine frozen semen. Animal Reproduction Science, v.68, p.344-345, 2001b.

DEMICK, D.S.; VOSS, J.L.; PICKETT, B.W. Effect of cooling, storage with glycerolization and spermatozoa number on equine fertility. Journal of Animal Science, v.43, p.633-637, 1976.

FAGUNDES, B.; TILBUG, M.F.Van; SOUZA, G.V. et al. Effect of addition of concentrated proteins and seminal plasma low molecular weight proteins in freezing and thawing of equine semens. Acta Biomedica Brasiliensia, v.2, p.1-6, 2011.

FERREIRA, H.N. Efeito da exposição aos crioprotetores glicerol e metilformamida na viabilidade e fertilidade do sêmen equino. 2008. 81f. Dissertação (Mestrado em Medicina Veterinária) Universidade Estadual Paulista, Botucatu.
FÜRST, R.; CARVALHO, G.R.; FÜRST, M.C.O. et al. Effect of the equine semen cooling onthe freezibility. Arquivo Brasileiro de Medicina Veterinária e Zootecnia, v.57, p.599-607, 2005.

GOMES, G.M.; JACOB, J.C.F.; MEDEIROS, A.S.L. et al. Improvement of stallion spermatozoa preservation with alternative cryoprotectants for Mangalarga Marchador breed. Theriogenology, v.58, p.277-279, 2002.

GRAHAM, J.K. Analysis of stallion semen and its relation to fertility. Veterinary Clinics of North America: Equine Practice, v.12, n.1, p.119-130,1996a.

GRAHAM, J.K. Cryopreservation of stallion spermatozoa. Veterinary Clinics of North America: Equine Practice, v.12, n.1, p.131-147,1996b.

HANADA, A.; NAGASE, H. Cryopretective effects of some amides on rabbit spermatozoa. Journal of Reproduction and Fertility, v.60, p.247-252, 1980.

HARRISON, R.A.P.; VICKERS, S.E. Use of fluorescent probes to acess membrane integrity in mammalian spermatozoa. Journal of Reproduction and Fertility, v.88, p.343-352, 1990.

HOLT, W.V. Basic aspects of frozen storage of semen. Animal Reproduction Science, v.62, p.3-22, 2000.

JASKO, D.J. Procedures for cooling and freezing of equine semen. Ars Veterinária, v.10, p.156-165, 1994.

MARTIN, J.C.; KLUG, E.; GÜNZEL, A.R. Centrifugation of stallion semen and its stored in large volume straw. Journal Reproduction and Fertility, suppl., v.27, p.47-51, 1979.

MC KINNON, A.O.; VOSS, J.L. Equine reproduction: London: Lea \& Febiger, 1993. 1.137p.

MEDEIROS, A.S.L. Resistência osmótica, congelabilidade e fertilidade do semen de garanhões frente a diferentes crioprotetores. 2007. 123f. Tese (Doutorado em Medicina Veterinária) - Faculdade de Medicina Veterinária e Zootecnia/ Universidade Estadual Paulista, Botucatu.

MEDEIROS, A.S.L.; GOMES, G.M.; CARMO, M.T. et al. Cryopreservation ofstallion sêmen using different amides. Theriogenelogy, v.58, p.273-76, 2002.

MELO. C.M.; ZAHN, F.S.; MARTIN, I. et al. Influence of semen storage and cryoprotectant o post-thwa viability and fertility of stallion spermatozoa. Journal of Equine Veterinary Science, v.27, n.4, p.171-175, 2007. 
PACE, M.M.; SULLIVAN, J.J. Effectofinsemination, number of spermatozoa and extender components on the pregnancy rate in mares inseminated with frozen stallion semen. Journal of Reproduction and Fertility Supplement, v.23, p.115-121, 1975.

PAPA, F.O.; DELL'AQUA JUNIOR., J.A. Effect of the type of filling and defreezing method on the spermatic parameters and fertility rate of the equine frozen semen. In: CONGRESSO BRASILEIRO DE REPRODUÇÃO ANIMAL, 14., 2001, Belo Horizonte. Anais... Belo Horizonte: CBRA, 2001. p.458.

PAPA, F.O.; ZAHN,F.S.; DELL'AQUA, J.A. et al. Utilization of MP5O diluter for the equine semen cryopreservation. Revista Brasileira de Reprodução Animal, v.26, p.3, 2002.

PAPA, F.O.; CAMPOS FILHO, E.P.; ALVARENGA, M.A. et al. Influence of the packing way on the acrosome and thermo resistance of the equine frozen semen. In: CONGRESSO BRASILEIRO DE REPRODUÇÃO ANIMAL, 9., 1991, Belo Horizonte. Anais... Belo Horizonte: CBRA, 1991. p.46.

PARKS, J.E.; GRAHAM, J.K. Effects of cryopreservation procedures on sperm membranes.Theriogenology, v.38, p.209-22, 1992.
PARKS, J.E.; LYNCH, D.V. Lipid composition and thermotrofic phase behavior of boar, bull, stallion and rooster sperm membrane. Cryobiology, v.29, n.2, p.255-266,1992.

SNEDCOR, G.W.; COCHRAN, W.G. Statistical Methods. Ames: Iowa State University, 1980. 505p.

TERRACIANO, P.B.; BUSTAMANTE FILHO, I.C.; MIQUELITO, L.V. et al. Equine spermatozoa cryopreservation comparing two freezing curves with commercial diluters: a laboratory analysis. Ciência Rural, v.38, n.7, p.1972-1977, 2008.

TSELUTIN, K.; SEIGNEURIN, F.; BLESBOIS, E. Comparison of cryoprotectants and methods of crypreservation of fowl spermatozoa. Poultry Science, v.78, p.586-590, 1999.

VIDAMENT, M.; YVON, J.M.; COUTY, I. et al. Advances in cryopreservation of stallion semen in modified INRA82. Animal Reproduction Science, v.68, p.201-218, 2001.

ZÚCCARI, C.E.S.N. Efeito da criopreservação sobre a integridade estrutural da célula espermática eqüina. 1998. 121f. Tese (Doutorado em Medicina Veterinária) - Faculdade de Medicina Veterinária e Zootecnia/Universidade Estadual Paulista, Botucatu. 